\title{
Nationalism of History Education: A Perspective on Indonesian History Text Books
}

\author{
Samudra Eka Cipta \\ History Education Department, Indonesian Education University \\ samudraeka97@gmail.com
}

\section{Keyword:}

Nationalism,

Indonesia,

Historical education, Historiography.

\section{ABSTRACT}

The journey of the Indonesian Nation has begun since the historical period which means that the Indonesian Nation has begun to recognize the tradition of writing as an effort to record the history of its ancestors. The development of the Indonesian nation continues to experience dynamics in each period. From these dynamics then there is an effort to strengthen and unite the Indonesian Nation through nationalism. Nationalism in Indonesia began in 1901-1920 or known as the Early Period of the Indonesian Movement with the marking of movement organizations both oriented towards education and politics. The history of Nationalism in Indonesia is not limited to the Era of Movement but continues to move today. Historical education was born and departed through the History of the Development of the Indonesian Nation. Of course, in the historiography of the Indonesian people is full of records of the struggle of how the founding fathers of the nation fought to establish the Republic of Indonesia through bloodshed. Certainly the essence of Historical Education is how efforts to increase the values of nationalism are presented in the form of historiography. This research has problem formulation which consists of (1) how is the development of historiography in Indonesia?,(2) how is nationalism related to history textbooks, (3) how is the concrete form of nationalism in historical education?.

\begin{tabular}{|c|c|c|}
\hline 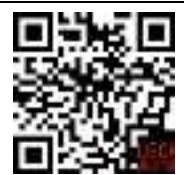 & $\begin{array}{l}\text { Article History: } \\
\text { Received: 30-01-2020 } \\
\text { Revised : 19-03-2020 } \\
\text { Accepted: 06-04-2020 } \\
\text { Online : 09-04-2020 }\end{array}$ & $\begin{array}{l}\text { This is an open access article under the CC-BY-SA license } \\
\text { https://doi.org/ } 10.31764 / \text { iieca.v3il.2034 }\end{array}$ \\
\hline
\end{tabular}

\section{A. INTRODUCTION}

Discussions on nationalism have often been discussed at scientific forums and as a training center for the cadres of an organization. Nationalism seems to be a label for every person by saying " NKRI Dead Prices " etc. However, nationalism is often used as a tool or political interest of the rulers to maintain power as an effort to form a government oligarchy. This is outlined in the curricula created through government intervention and even the political elements contained therein.

One of the essence of historical education for the interests of the country is to increase the sense of nationalism by including historical events that are political and filled with a history of political conflict, especially from the Indonesian Independence Revolution Period (1945-1949) to the Reformation Period (1998-present). This is done by the government as an asset to defend the country as part of the geostrategic concept that was built to build the nation's collective memory. 
Indonesian national history textbooks in the New Order era contain many political elements based on " supremacy of power ". The government publishes a book on Indonesian National History consisting of volumes 1-6. The book is now a reference in history subject matter in schools. The entire contents or material presented in the textbook greatly legitimizes the dominant role of the New Order Government as well as a form of 'Desukarnoization' so that the role of the New Order is more dominant than Sukarno's role in the development of historiography in Indonesia. Especially when NugrohoNotosusanto was appointed as the head of the Indonesian National History Book preparation team, making him indoctrination of the government in textbooks. Not all of the events that took place during the years 1960-1967 until the beginning of the New Order Government were included as subject matter in textbooks. For example the events of the Malaysia Malaysia Confrontation that occurred in 1962 were not included in the material because they were only a propaganda of the Eastern Bloc when Soekarno opposed British influence on the Malay Peninsula while in fact for the New Order these events were in the interests of the Soviet Union. Another proof of the legitimacy of the power of the New Order through the Indonesian National History Textbook is when the integration of East Timor in 1975 was marked by the Balibo Declaration which indicated that the New Order had contributed greatly to the East Timorese Community. The East Timorese people at that time called it the Balibo (hong) declaration because it was considered full of engineering by the New Order intelligence. The New Order government which at the time echoed the 'Repelita' Five-Year Development Plan was also widely written in the Indonesian National History Textbook (Kurniawan \& Suwirta, 2016).

From the facts mentioned above is evidence as well as criticism and challenges of how the efforts of the interests of the government in indoctrination of the Indonesian Community through history textbooks have been taught since school age. This is a challenge as a history subject teacher in conveying the facts that happened in the past without having to put aside the values of nationalism taught in schools. During this time, many facts in the textbook have been lost or hidden by previous policies. Historians do a lot so that the public's access to historical knowledge containing some of the lost facts is very limited and only through certain scientific forums. History teacher, of course, is a teacher who is able to reveal various facts that actually occur by presenting several points of view to avoid misunderstanding with one another. Because actually, learning history is not concerned with right and wrong but rather the interpretation or interpretation of an event is emphasized in the study of history.

In another perspective, nationalism is only a slogan in writing. The fact is, not everyone understands the meaning of nationalism. If you take the concept of Indonesianness according to NurcholisMadjid which says that between religion and tolerance is something that can be united. For example when Masyumi in 1960 tried to take steps to form the Pan-Islamist movement in Indonesia, however, it was later opposed by Sukarno so that Masyumi was dismissed of his party status. For this reason, CakNur calls from NurcholisMadjid to express the idea of 'Yes Islam, Islamic Party No'. Actually what was conceived by NurcholisMadjid meant that something that was considered sacred (in the sense of Islamic matters) should not be used as a foundation in state politics. This is when reviewing political developments in Indonesia since the DI / TII until the New Order era there were continuing conflicts between nationalists and Islamists. So that both of them continue to strive to gain political existence in the development of Indonesian History (Ibda, 2017).

Cak Nur is a number of scientists who can understand the concept of nationalism and how the views of most people about the relationship of religion with nationalism are very contradictory. True nationalism can be united in religion depending on the context and the need to avoid misunderstanding in interpreting nationalism.

\section{B. METHODS}

The method used by the author is a content study method that is using a literature study approach from several sources by examining a number of findings in the form of collecting books as a reference source as well as comparing the sources in this discussion. The author also 
uses historical methods to see the development of historical learning in Indonesia by looking at historical events in Indonesia. According to HeliusSjamsuddin, said that the historical method begins with the stages of data collection, criticism or verification, interpretation, and writing history as a framework for thinking in a historical study (Sjamsuddin, 2012).

According to Klaus Kripendoff, content analysis is not merely making the message content its object, but is also related to more recent conceptions of symbolic phenomena in the world of communication. Content analysis is a research technique for making inferences or information that can be replicated and valid of the data by paying attention to the context (Suprayogo et al., 2019).

\section{RESULT AND DISCUSSION}

\section{Development of Historiography from Neerlandocentric to Indonesiacentric}

Since the beginning of Indonesian independence, the development of historical writing has met a new chapter. Political factors have changed the pattern of historical writing towards Indonesia. That is because since the period of the Dutch Colonial Population the historiography style still strongly refers to the problem of population in Indonesia. The development of the historiography of Modern Indonesia began on December 14-18, 1957, when the Ministry of Education held the first National History Seminar in Yogyakarta to design an official national history. National development was one of the main themes in the 1950 s and writing national history is an inseparable part of this process. The seminar talked about the effort to write a national history with an Indonesian centric view. National history is expected to be a unifying tool by providing an explanation of the existence of the Indonesian nation through its historical footprint. The events that took place in Indonesia were written by Indonesians themselves, and thus their objectivity could be accounted for because those who wrote history were the people who were at the time the events occurred or at least were native Indonesians.

On the other hand, long before the holding of the National Seminar on History I the effort to bring up Indonesian writing was already present when there was a dissertation by HuseinDjadjadiningrat, a Regent of Serang and had been a student of SnouckHurgronje. The dissertation was reviewed by Husein Djadjadiningrat (1913) when he was to be tested at Leiden University. One of Husein's dissertations is Critische Beschouwing van de Sadjarah Banten (1913) which examines the problem of writing the history of Banten. In the writing of the history of Banten Husein saw that there was still a writing style that was Nerlandocentric. For example the book Max Havelaar (1860), the work of Multatuli which tells the fate of indigenous suffering but the book also explains the involvement of the Colonial Government in saving the fate of the people of Banten by implementing the Reply Politics of Budi. Ethical Policy is carried out by allowing indigenous people to obtain education. Initially the purpose of implementing Ethical Politics with two goals, the goals that appear outside are as if penetrating the mistakes of the Forced Cultivation Politic committed. However, behind that, the purpose is hidden, to meet the needs of low-level administrative staff. which ideally does not need to be done by "the Dutch". However, enough is done by indigenous workers who have been "schooled". (Multatuli, 1987)

Apart from the intent above Post National Seminar History I historians and politicians work together to write the Indonesian National History. There is something interesting about the two figures, namely between Mr. Muhammad Yamin with Sartono Kartodirdjo. The two figures have different backgrounds so that works related to Indonesian National History also have different styles. Muhammad Yamin has written extensively on the History of Indonesia, one of the books he wrote, entitled 6000 Years of the Red and White (1951). The book examines how the history of the long journey of the Red and White Flags existed long before the Independence of Indonesia, but since the Kingdom of Majapahit using the 'Red and White' color of the flag elements as the symbol of the kingdom. For some historians Muh. Yamin is considered to always obscure the facts in constructing Indonesian 
History. No exception when Muh. Yamin depicts the figure of Gadjah Mada, who almost resembles himself and seems to be portrayed as a real figure. Then, Sartono Kartodirdjo published a work on Indonesian historiography by emphasizing the role of local figures in an event. The work in question is titled Banten Peasant Rebellion 1888 (1966) the book is an anti-thesis, written by Sartono as a criticism, of Dutch-centric colonial historiography; emphasizes government institutions and considers the people and peasants to play a passive role. The book evokes the writing of local history, which turned out to be complex and meaningful. The multi-dimensional approach used by Sartono is equally important in the book.

The statement above is said that in 1950-1960 was the beginning of the Resurrection of Indonesian History Writing with the Indonesian approach.However, in the beginning to reconstruct an event historians still see mythology as a big role in a society's turmoil.The social movement in question is still influenced by the RatuAdil concept, a concept that all suffering will disappear when someone emerges from the shackles of suffering.This concept was built for centuries and is often used when trying to carry out a movement against the Dutch Colonial Government because it is considered as a source of suffering for the people of Bumiputera at that time.

\section{Analysis of Historical Textbooks of the New Order}

The New Order period was the most important mass in the development of historiography, especially in the History Textbooks at school. The New Order government then undertook a 'project' for the making and printing of the Indonesian National History Book consisting of 6 volumes and collaborating through Balai Pustaka as the main printing press. In the process of compiling the SNI Book (Sejarah Nasional Indonesia) the role of military officials was needed by the government at that time. This is with the appointment of Nugroho Notosusanto as chairman in the preparation of the SNI Book. ABRI's background Nugroho Notosusanto is able to write SNI and has a writing style that is very emphasizing the role of ABRI and the New Order in writing historical textbooks in Indonesia. The figure of NugrohoNotosusanto is considered very controversial Nugroho even criticized him openly, call it A. Surjomihardjo, Kuntowijoyo \& Onghokham. Perhaps this is what led Nugroho to get the stigma of a failed historian because of his outstanding \& controversial work in the writing of history (version) of the New Order. (Miharja \& Mulyana, 2019)

The mention of the term New Order in the writing of Indonesia's National History reflects the interpretation of power. The terminology of the New Order shows that Indonesia's National History is a history of struggle. The struggle began with the colonial era, a struggle full of wars in expelling invaders or struggles between nationalist forces against colonials (invaders). The outcome of this struggle gave birth to an independent state, the Republic of Indonesia (Kurniawan \& Suwirta, 2016). When Indonesia's independence was not over, various kinds of threats and disruptions arose for the existence of the Republic of Indonesia. Disturbances and threats are in the form of physical conflict or armed struggle or political upheaval. Threats and interference both come from outside and from inside. The challenge from outside is the coming back of the Dutch who wanted to colonize Indonesia so that there was a war or armed conflict between the Indonesian and the Dutch. This period is known as the Revolutionary Period. While the internal threat is in the form of rebellions that are considered to undermine the sovereignty of the Republic of Indonesia. The rebellions were like PRRI / PERMESTA, PKI, DI / TII, RMS, and so on. The existence of the Republic of Indonesia can finally be saved by a power which then forms a government called the New Order. The main force that supported the New Order was the military. Thus during the New Order era militarization occurred in history (Terry \& McGregore, 2002).

Indonesia's National History reconstructed by the New Order is a National History full of interpretations of power. National History Writing is basically a promotion from the government, because national history is closely related to state legitimacy and national identity (Sutherland, 2009). The New Order tried to make one identity or define it itself, 
namely a total correction of abuses in all fields, and tried to reorganize the strength of the Nation and determine appropriate ways to foster long-term national stability so as to accelerate the Nation-building process based on the PANCASILA and the Law Basic 1945 (Nugraha \& Setiawan, 2019). The government that took place before the New Order was interpreted as a condition that was no better than the New Order government even interpreted with a counterproductive condition so that it was called the Old Order.

\section{The Development of Nationalism and Its Context in Indonesian History Textbooks}

In history, Nationalism originated in the European continent around the Middle Ages. National awareness was triggered by the Protestant Reformation movement spearheaded by Martin Luther in Germany. European nationalism at its inception produced a declaration of human rights but eventually turned into a policy based on strength and self-interest and not on humanity. In its development European nationalism moved into a national fanaticism competition between European nations which gave rise to colonization of countries that did not yet have a national identity (nationalism) in the continents of Asia, Africa and Latin America. This fact refers to two things:

a. The European economic boom at that time resulted in an abundance of production.

b. The view of the Italian thinker, Nicolo Machiaveli, who encouraged a ruler to do anything to maintain the existence of his power. He wrote: "If this is an absolute problem regarding the welfare of our nation, then we should not pay attention to justice or injustice, mercy or ignorance, praise or humiliation, but to set aside all using any tactics that save and preserve the life of our country.

Nationalism which initially concerned human rights at a later stage considered the collective power realized in the state to be more important than individual independence. The view that made the country the centre was the view of several European thinkers at the time, including Hegel. He argues that the interests of the state take precedence in the relations of state society, because they are objective interests while the interests of each individual are subjective interests.

In Indonesia the history of nationalism occurred in 1901-1920 as the beginning of the emergence of various movement organizations in Indonesia. According to Kahin (Kahin, 2015), said that the Movement Period other than the period where the beginning of the revival to fight the Colonial Government system, the Movement Period was known as a form of ideological struggle along with its existence, especially between the nationalist reformist movement and the pan-Islamism movement as a rival force in realizing the movement. in Indonesia. The initial period of the movement will be a new chapter in the writing of historiography in Indonesia along with the awareness of the formation of entities and national identity supported by science.

Then, the regime used educational institutions as an effort to maintain power with the formation of " apparatus " education (Sotiris, 2009). The power that is built is the ideologies that are included in the curriculum made. One of the practices of state ideology through the education apparatus, with regard to aspects of ideology and historical legitimacy, appears in the form of history textbooks. As a historical paper, history textbooks are also historiographical works. However, it is different from other types of historiography, especially historiography which is historically oriented solely and without the political purpose of historiographical education. Historical textbooks are historiographical genres, which try to meet the standards of historical science as well as for the benefit of education as well as the ideological medium of the state towards students.

Althausser further stated that the state holds a monopoly to determine what is right and wrong about the nature of the state, determine what is moral and what is not moral, as well as what is good and what is destructive (Simandjuntak, 2004). This gave rise to the tendency of nationalism to place too much emphasis on the homeland (patriotism that led to chauvinism), which encouraged European societies to expand into other parts of the world. 


\section{Learning History as the Formation of National Identity}

Learning history is a door to learn and find wisdom about what has happened. Studying history is learning about humanity in all its aspects. Studying history will give birth to an awareness of the nature of cultural development and human civilization, the result of this learning is what became known as historical consciousness (historical consciousness) (Kasim, 2016). So the purpose of learning history is to give birth to historical awareness. Thus, the process of learning history in schools must also be encouraged to create situations that can foster historical awareness.

History is inseparable from problems of power, politics, conflict, and so on. But today, writing history puts forward the social and locality aspects. The aspect of locality that is built is the locality aspect by prioritizing social figures who live or have a role in an event in their area. So what is known today is that local history is an agreement between the writer and social groups that are limited to locally, or limited geographical aspects (Nawawi \& Abdullah, 1996).

On the other hand, local history also involves aspects of social and cultural intermediaries as the formation of an event in a particular area. In fact, the local history of regional unity by involving the development of community groups from an environment naturally underwent a change accompanied by certain dynamics (Widja, 2018).

Learning history must use a lococentric approach, namely learning history with a foundation in local history. The teacher must understand the principle of time parallelism in presenting events, and must also understand local history. Thus, the teacher will always associate national events with events in the area where he is working. For example, when discussing the Proclamation Event, the teacher must also explain at the same time what he was assigned to do in the area. Material linkages and discussion will involve not only the mind but also emotional, so that it will give birth to an awareness of the continuity of past history with what is happening now.

\section{The Challenges of Learning History Today}

During the Reformation era after the New Order era, the writing of history in historical text books continued to be influenced by political interests. This was revealed by Niels Mulder, a Dutch historian, who said that the writing of books since the New Order period more closely reflects current ideological thinking. Subjects such as history, citizenship, and other social studies (IPS) such as Sociology, Anthropology, and Economics in schools are areas that are vulnerable to the influence of ideology and political interests of the government. Actually, all of that was constructed by the government in order to maintain part of geo-strategy as to maintain power and the state (Suwirta, 2009).

Curriculum changes that are made continuously also create new problems for the development of history writing that is adjusted to KD (Kompetensi Dasar) and IPK (Indikator Ketercapaian Kompetensi) to make teachers especially AGSI (Asosiasi Guru Sejarah Indonesia) have to work hard in preparing the history learning curriculum. Moreover, some time ago it was shocked by the government's discourse to abolish history lessons because they were considered ancient. Of course the discourse is very anxietycausing especially experienced by history teachers so that it can threaten the professionalism of the history teacher. Even though the discourse did not actually happen and the history teacher still carried out the tasks according to their respective functions.

When quoting the philosophy of " Historia Vitae Magistra " which means history is the teacher of history learning life has an ideal goal that is as an effort to improve the life of the nation and state that begins with a group of people without the interference of power and political interests so as to reduce the essence of historical education as should be. 


\section{CONCLUSION AND SUGGESTIONS}

Historical learning actually increases the understanding of nationalism apart from the efforts of political interests built by the authorities to shape the collective memory of the Indonesian people. The narration made is ideological. Historical narratives filled with chronological facts and educational interpretations that are educational in nature are referred to as "ideologization", which transmits the government's ideology or views of students at school, so that students' views will be the same, as desired by the ruling government.

Not only at the level of narration, but in the curriculum that was formed was also very politically charged so that there was an assumption that in exchange for leadership, then also replace the curriculum that made history lessons must 'adjust' to the interests of the rulers during their tenure. This can actually eliminate the main image or essence of history learning as an experience teacher in order to change something new.

\section{REFERENCES}

Ibda, H. (2017). Relasi Nilai Nasionalisme Dan Konsep Hubbul Wathan Minal Iman Dalam Pendidikan Islam. International Journal Ihya' 'Ulum Al-Din, 19(2). https://doi.org/10.21580/ihya.19.2.1853

Kahin, A. R. (2015). Indonesia's mid-life crisis, 1978-1995. Indonesia, 2015(100), 19-24. https://doi.org/10.5728/indonesia.100.0019

Kasim, M. (2016). Hukum Islam Dan Kontribusinya Pada Hukum Nasional. Jurnal Ilmiah Al-Syir'ah, 8(1). https://doi.org/10.30984/as.v8i1.43

Kurniawan, M. D., \& Suwirta, A. (2016). Ideologisasi Konsep Reformasi dalam Historiogra fi Buku Teks

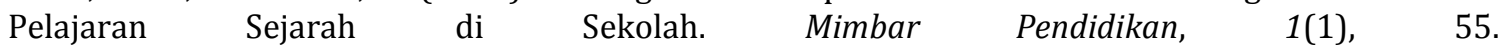
https://doi.org/10.17509/mimbardik.v1i1.1753

Miharja, D., \& Mulyana, M. (2019). Religious: Jurnal Studi Agama-Agama dan Lintas Budaya. In Religious: Jurnal Studi Agama-Agama dan Lintas Budaya (Vol. 3, Issue 2). https://journal.uinsgd.ac.id/index.php/Religious/article/view/4717/pdf

Multatuli. (1987). Max Havelaar, or, The coffee auctions of a Dutch Trading Company. In Penguin classics. (p. viii, 337 p.).

Nawawi, M. N. M., \& Abdullah, M. Z. (1996). Application of geophysical methods for quantitative archaeological investigations. 1996 SEG Annual Meeting, 770-773. https://doi.org/10.1190/1.1826765

Nugraha, W., \& Setiawan, A. (2019). Sukarno's Ideas In Indonesian Foreign Policy. Book Chapters of The 1st Jakarta International Conference on Social Sciences and Humanities (JICoSSH), 1, 1-19. https://doi.org/10.33822/jicossh.v1i1.2

Simandjuntak, M. (2004). Indonesian decentralization: Opportunities appear but risks abound. In Reforming Intergovernmental Fiscal Relations and the Rebuilding of Indonesia: The "Big Bang" Program and its Economic Consequences (pp. 261-271). https://doi.org/10.4337/9781845421656.00019

Sjamsuddin, H. (2012). Model Pendekatan Pembelajaran Sejarah Dari Isus-Isu Kontroversial, SejarahKomparatif Ke Analisis Tekstual. AGASTYA: Jurnal Sejarah Dan Pembelajarannya, 2(1). https://doi.org/10.25273/ajsp.v2i1.764

Sotiris, P. (2009). Louis Althusser Louis Althusser and the traditions of French Marxism Althusser: The detour of theory. In Historical Materialism (Vol. 17, Issue 4, pp. 121-142). https://doi.org/10.1163/146544609X12537556703359

Suprayogo, R., Sutrisno, S., \& Supandi, S. (2019). Eksperimentasi Pendekatan RME terhadap Prestasi Belajar Matematika Ditinjau dari Motivasi Belajar Siswa. Media Penelitian Pendidikan: Jurnal $\begin{array}{lllll}\text { Penelitian Dalam Bidang Pendidikan Dan Pengajaran, 13(2), } 189 . & \end{array}$ https://doi.org/10.26877/mpp.v13i2.5103

Sutherland, C. (2009). Industrial legislation in 2008. Journal of Industrial Relations, 51(3), 297-311. https://doi.org/10.1177/0022185609104299

Suwirta, A. (2009). The History of Education in West Java, Indonesia: From Traditional Era toward Modern Era. Educare: International Journal for Educational Studies, 1(2), 129-140. http://www.journals.mindamas.com/index.php/educare/article/view/197/196 
Terry, A. M. R., \& McGregore, P. K. (2002). Census and monitoring based on individually identifiable vocalizations. Animal Conservation, 5(02), 103-111. http://journals.cambridge.org/action/displayAbstract?aid=108159 \npapers3://publication/doi/10 .1017/S1367943002002147\nhttp://dx.doi.org/10.1017/S1367943002002147

Widja, I. G. (2018). Pembelajaran Sejarah Yang Mencerdaskan Suatu Alternatif Menghadapi Tantangan dan Tuntutan Jaman yang Berubah. Jurnal Pendidikan Sejarah Indonesia, 1(2), 117-134. https://doi.org/10.17977/um033v1i22018p117 